\title{
PEMANFAATAN CITRA SATELIT UNTUK PENENTUAN LAHAN KRITIS MANGROVE DI KECAMATAN TUGU, KOTA SEMARANG
}

\author{
D.A. Ardiansyah ${ }^{\mathrm{a}}$, I.Buchori ${ }^{\mathrm{b}}$ \\ a Universitas Diponegoro, Indonesia, email: deniesyach@gmail.com \\ ${ }^{b}$ Universitas Diponegoro, Indonesia, email: i.buchori@undip.ac.id
}

\begin{abstract}
Article Info;
Abstract: This study aims to mapping the level of degraded land of mangrove forest area In

Received: TUGU Sub-district, Semarang, by comparing the results between the Landsat 7 ETM + images 10 February 2014 of 2009 and ALOS AVNIR-2 in 2009. In determining the degradation of mangrove forest area, we used geographic information systems and remote sensing as a tool of analysis that is based on three (3) criteria; land use type, canopy density, and soil resilience from abrasion. From 2 in revised form: 1 March 2014 satellite image data used, it will be supervised image classification using ER Mapper software to get the criteria type of land use and density of the canopy. For soil resilience from abrasion,

Accepted: we used soil types reclassification techniques, using ArcGIS software. Based on Landsat 10 March 2014 imagery, obtained results $92.22 \%$ of mangrove forest area included in severely damaged condition and $7.78 \%$ is included in the category of moderate damage. Meanwhile, based on the

Available Online: 25 March 2014

\section{Keywords:}

Satellite Imagery,

Critical Land, results of ALOS image, $77.73 \%$ of mangrove areas in severely damaged condition and $22.27 \%$ are included in the category of moderate damage. From this study, it can be concluded that ALOS and Landsat Imagery is good for the determination and identifying critical mangrove area and distribution of mangrove forests, but the degraded land of mangrove maps generated by Landsat, less detailed than ALOS in classification and representation the conditions of critical mangrove area in Tugu sub-district.
\end{abstract}

Mangrove, GIS,

Remote Sensing

\section{Info Artikel;}

Diterima:

10 February 2014

Hasil Revisi :

1 Maret 2014

Disetujui:

10 Maret 2014

Publikasi On-Line:

25 Maret 2014

\section{Kata kunci:}

Citra Satelit, Lahan

Kritis, Mangrove, SIG,

Penginderaan Jauh.

\begin{abstract}
Abstrak: Penelitian ini bertujuan memetakan tingkat kekritisan lahan hutan mangrove dengan membandingkan hasil antara Citra Landsat 7 ETM+ tahun 2009 dan Citra ALOS AVNIR2 tahun 2009. Dalam penentuan lahan kritis hutan mangrove ini digunakan sistem informasi geografis dan penginderaan jauh sebagai alat bantu analisis yang didasarkan pada 3 (tiga) kriteria, antara lain, Jenis penggunaan lahan, Kerapatan tajuk, dan Ketahanan tanah terhadap abrasi. Dari 2 data citra satelit yang digunakan akan dilakukan klasifikasi citra terbimbing dengan menggunakan software ER Mapper untuk mendapatkan kriteria Jenis penggunaan lahan dan Kerapatan tajuk. Untuk kriteria Ketahanan Tanah Terhadap Abrasi menggunakan teknik reklasifikasi peta jenis tanah dengan menggunakan software ArcGIS. Dari penelitian yang telah dilakukan, berdasarkan Citra Landsat diperoleh hasil 92,22\% kawasan hutan mangrove termasuk dalam kondisi rusak berat dan 7,78\% termasuk dalam kategori rusak sedang. Sedangkan bedasarkan hasil dari Citra ALOS sebanyak 77,73\% kawasan mangrove di Kecamatan Tugu termasuk dalam kondisi rusak berat dan 22,27\% termasuk dalam kategori rusak sedang. Dari penelitian ini dapat disimpulkan bahwa Citra ALOS dan Citra Landsat sudah baik untuk penentuan lahan kritis mangrove khususnya dalam identifikasi luasan dan sebaran hutan mangrove di suatu kawasan, tetapi peta lahan kritis mangrove yang dihasilkan oleh citra Landsat kurang mempresentasikan secara detail pengklasifikasian kondisi lahan kritis mangrove di Kecamatan Tugu.
\end{abstract}

\section{PENDAHULUAN}

Hutan mangrove merupakan salah satu ekosistem pesisir tropis atau sub-tropis yang sangat dinamis serta mempunyai produktivitas, nilai ekonomis, dan nilai ekologis yang tinggi. Faktor-faktor lingkungan juga berperan penting dalam menentukan keanekaragaman, distribusi, dan peranan secara ekologis dari faunafauna dalam ekosistem hutan mangrove. Kadar garam, lama periode penggenangan, dan suhu pada permukaan hutan mangrove menjadi faktor pembatas utama bagi penyebaran fauna yang hidup di dalamnya (Susetiono, 2005). Secara umum dari hasil survei ekosistem mangrove di kawasan pesisir Kota 
Semarang sudah mengalami degradasi, kerusakan tersebut sejalan dengan perkembangan kota yakni pembukaan lahan di wilayah pesisir untuk budidaya tambak intensif, untuk kawasan permukiman, kawasan industri dan kawasan pelabuhan. Berdasarkan kondisi tersebut disimpulkan secara umum kerusakan ekosistem mangrove di kawasan pesisir Kota Semarang sudah mencapai $90 \%$ dan dalam kategori rusak berat/tutupan lahan di bawah 25\% (RTRWP Kota Semarang, 2009). Perda Kota Semarang Nomor 7 Tahun 2010 tentang Penataan Ruang Terbuka Hijau (RTH) pasal 27, menyebutkan bahwa luas RTH Kawasan Pantai Berhutan Bakau Wilayah Kecamatan Tugu ditetapkan sebesar $\pm 225,000$ ha. hal tersebut menunjukan bahwa terjadi kesenjangan antara peraturan yang ada dengan kondisi sebenarnya di lapangan. Akibat dari degradasi hutan mangrove di Kecamatan Tugu antara lain adalah selama periode 1991-2010 garis pantai mundur mencapai 1,7 km dengan area genangan mencapai 1.211,2 ha (BAPPEDA Kota Semarang, 2012). Hal tersebut disebabkan oleh hilangnya fungsi mangrove sebagai pemecah gelombang laut penyebab bencana abrasi. Tanaman mangrove memiliki salah satu ciri khas yaitu akar berongga sehingga dapat memantulkan gelombang dan menahan sedimen secara periodik sampai terbentuk lahan baru (Arief, 2003).

Setiap citra digital yang dihasilkan oleh setiap sensor mempunyai sifat khas datanya. Sifat khas data tersebut dipengaruhi oleh sifat orbit satelit, sifat dan kepekaan sensor penginderaan jauh terhadap panjang gelombang elektromagnetik, jalur transmisi yang digunakan, sifat sasaran (objek), dan sifat sumber tenaga radiasinya. Sifat orbit satelit dan cara operasi sistem sensornya dapat mempengaruhi resolusi dan ukuran pixel datanya (Purwadhi dan Sri Hadianti, 2001).Dalam penentuan lahan kritis hutan mangrove diperlukan data citra satelit yang digunakan sebagai data. Citra satelit tentunya memiliki karakteristik masing-masing bedasarkan berbagai kriteria yang terdapat di citra satelit tersebut. Oleh karena itu, diperlukan data citra satelit yang tepat dalam penentuan lahan kritis hutan mangrove. Wilayah yang akan di lakukan penelitian adalah7 kelurahan di Kecamatan Tugu diantaranya yaitu: Jrakah, Tugurejo, Randugarut, Karanganyar, Mangkan Kulon, Mangunharjo, dan Mangkan Wetan. Untuk lebih jelasnya dapat dilihat pembagian wilayah studi pada Gambar 1 berikut.

Gambar 1.Wilayah studi Kecamatan Tugu, Kota Semarang (Bappeda Kota Semarang, 2010)

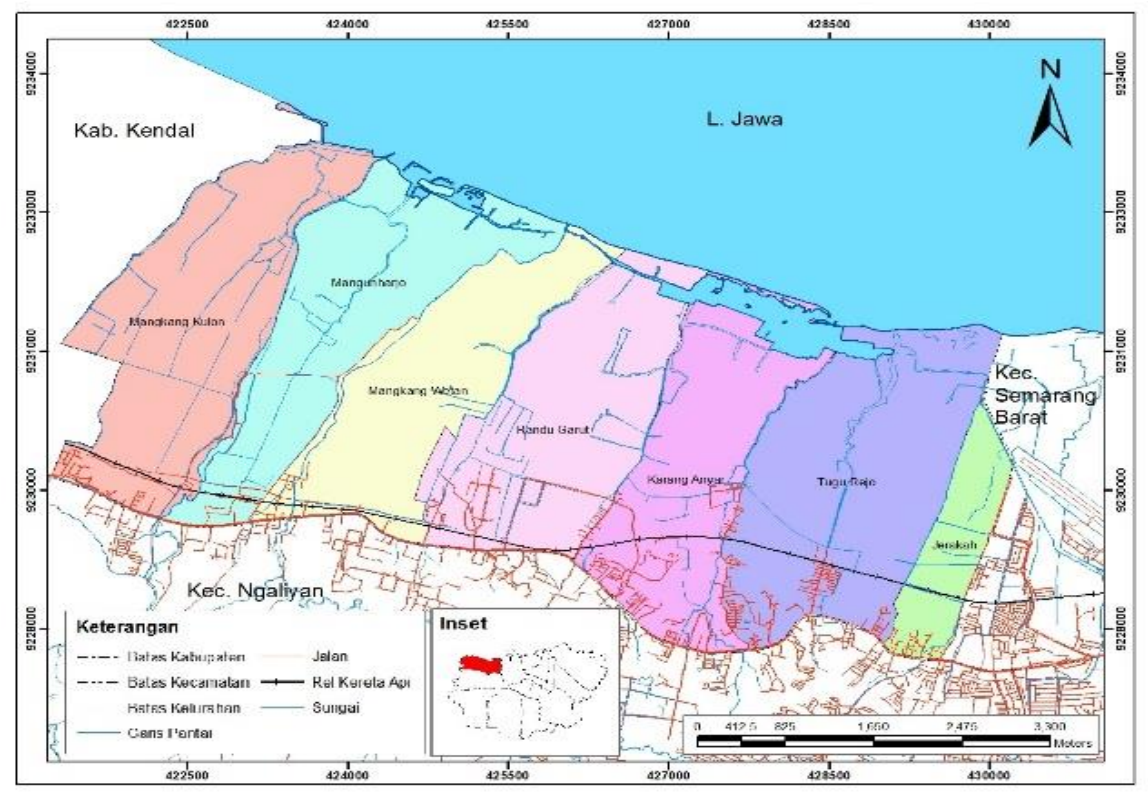

\section{DATA DAN METODE}

Pada mulanya, hutan mangrove hanya dikenal secara terbatas oleh kalangan ahli lingkungan, terutama lingkungan laut. Mula-mulanya, kawasan hutan mangrove dikenal dengan istilah Vloedbosh, kemudian dikenal dengan istilah payau, karena sifat habitatnya yang payau. Bedasarkan dominasi jenis pohonnya, yaitu bakau, maka kawasan mangrove juga disebut sebagai hutan bakau. Kata mangrove sendiri berasal dari bahasa portugis yaitu mangue yang berarti tumbuhan dan bahasa inggris grove yang berarti belukar atau hutan kecil (Arief, 2003). Hutan mangrove atau yang biasa disebut hutan bakau merupakan tipe hutan 
yang khas dan tumbuh disepanjang pantai atau muara sungai yang dipengaruhi oleh pasang surut air laut (SK Dirjen Kehutanan, 1978). Hutan mangrove mempunyai ciri-ciri umumnya tumbuh pada daerah intertidal yang jenis tanahnya berlumpur, berlempung dan berpasir; daerahnya tergenang air laut secara berkala, baik setiap hari maupun yang hanya tergenang pada saat pasang purnama. Frekuensi genangan menentukan komposisi vegetasi hutan mangrove; Menerima pasokan air tawar yang cukup dari darat (Bengen, 2000). Beberapa fungsi dari hutan mangrove secara fisik (Arief, 2003) antara lain untuk menjaga garis pantai agar tetap stabil; melindungi pantai dan tebing sungai dari proses erosi atau abrasi, serta menahan atau menyerap tiupan angin kencang dari laut ke darat; menahan sedimen secara periodik sampai terbentuk lahan baru; sebagai kawasan penyangga proses intrusi atau rembesan air laut ke darat, atau sebagai filter air asin menjadi air tawar.

Bedasarkan pedoman inventarisasi dan identifikasi lahan kritis mangrove yang diterbitkan oleh Departemen Kehutanan (2005), suatu lahan mangrove dapat dikategorikan sebagai lahan kritis, apabila lahan tersebut sudah tidak dapat berfungsi lagi, baik sebagai fungsi produksi, fungsi perlindungan maupun fungsi pelestarian alam. Kriteria-kriteria yang dapat digunakan untuk penentuan tingkat kekritisan lahan mangrove untuk masing-masing teknik penilaian adalah sebagai berikut (Departemen Kehutanan, 2005):

a) Jenis Penggunaan Lahan (JPL).Dalam pedoman inventarisasi dan identifikasi lahan kritis mangrove tahun 2005, Interpretasi penutupan lahan menggunakan metode 'digitize on screen'. Metode tersebut digunakan karena objek yang ditafsir berkorelasi kuat dengan objek air,sehingga pantulan air sangat mempengaruhi pantulan objek mangrove. Pada kondis demikian, penafsiran secara visual akan lebih menguntungkan karena unsu rsubjektivitas penafsir akan dibantu dengan pemahaman kunci penafsiran. Pada kriteria jenis penggunaan lahan ini, dapat diklasifikasikan menjadi tiga kategori (Departemen Kehutanan, 2005), yaitu: Hutan (kawasan berhutan), tambak tumpang sari dan perkebunan, dan areal nonvegetasi hutan (pemukiman, industri, tambak non tumpang sari, sawah dan tanah kosong).

Selanjutnya, dalam penentuan kerapatan tajuk mangrove ini digunakan forrmula NDVI. Prinsip kerja analisis NDVI adalah dengan mengukur tingkat intensitas kehijauan. Intensitas kehijauan berkorelasi dengan tingkat kerapatan tajuk vegetasi dan untuk deteksi tingkat kehijauan pada citra landsat yang berkorelasi dengan kandungan klorofil daun, maka saluran yang baik digunakan adalah saluran infra merah dan merah. Oleh sebab itu, dalam formula NDVI digunakan kedua saluran tersebut. Formula yang digunakan pada NDVI adalah sebagai berikut (Landgrebe, 2003):

$$
N D V I=\frac{\text { Saluran } 4-\text { Saluran } 3}{\text { Saluran } 3+\text { Saluran } 4}
$$

Keterangan :

- Saluran 3 : Nilai Spektral Saluran Merah

- Saluran 4 : Nilai Spektral Saluran Inframerah dekat

- NDVI : Normalized Defference Vegetation Index

Klasifikasi kerapatan tajuk mangrove ditentukan berdasarkan rentang nilai NDVI hasil perhitungan. Jumlah klasifikasi kerapatan mengacu pada buku Pedoman Inventarisasi dan Identifikasi Mangrove yang diterbitkan oleh Direktorat Jenderal Rehabilitasi Lahan dan Perhutanan Sosial Departemen Kehutanan. Pembagian klasifikasinya adalah sebagai berikut:

1. Kerapatan tajuk lebat $(0,43 \leq N D V I \leq 1,00)$

2. Kerapatan tajuk sedang $(0,33 \leq \mathrm{NDVI} \leq 0,42)$

3. Kerapatan tajuk jarang $(-1,00 \leq N D V I \leq 0,32)$

Dalam penentuan lahan kritis hutan mangrove ini, jenis-jenis tanah yang dapat diperoleh dari peta land system dan data GIS lainnya serta dikategorikan menjadi tiga kategori (Departemen Kehutanan, 2005), yaitu; jenis tanah tidak peka erosi (tekstur lempung), jenis tanah pekaerosi (tekstur campuran), jenis tanah sangat peka erosi (tekstur pasir). Sedangkan menurut kepekaannya terhadap erosi, tanah dapat dibagi ke dalam kelas-kelas sebagai berikut: 
Tabel 1. Jenis tanah menurut kepekaan terhadap erosi (Menteri Pertanian, 1980)

\begin{tabular}{ccc}
\hline Kelas Tanah & Jenis Tanah & Keterangan \\
\hline $\mathbf{1}$ & Aluvial, Tanah Glei Planosol Hidromorf Kelabu, Literita Air Tanah & Tidak Peka \\
$\mathbf{2}$ & Latosol & Agak Peka \\
$\mathbf{3}$ & Brown Forest Soil, Non Calcis Brown, Mediteran & Kurang Peka \\
$\mathbf{4}$ & Andosol, Laterit, Grumosol, Podsol, Podsolik & Peka \\
$\mathbf{5}$ & Regosol, Litosol, Organosol, Renzina & Sangat Peka \\
\hline
\end{tabular}

Berdasarkan 3 kriteria penentu lahan kritis hutan mangrove di atas, total nilai skori (TNS) dihitung dengan rumus sebagai berikut (Departemen Kehutanan, 2005):

$$
\text { TNS }=(J P L \times 45)+(\text { KT } \times 35)+(\text { KTA } \times 20)
$$

Keterangan;

TNS : Total Nilai Skor

JPL : Skor jenis penggunaan lahan

KT : Skor kerapatan tajuk

KTA : Skor ketahanan tanah terhadap abrasi

Dari total nilai skor (TNS), selanjutnya dapat ditentukan tingkat kekritisan lahan mangrove sebagai berikut:

- Nilai $100-166$ : Rusak Berat

- Nilai 167-233: Rusak

- Nilai 234-300 : Tidak Rusak

Setelah kriteria diperoleh, penentuan lahan kritis hutan mangrove dilakukan beberapa tahap klasifikasi dalam mendapatkan variabel yang telah ditentukan. Dalam penentuan beberapa variabel seperti, jenis penggunaan lahan dan kerapatan mangrove, digunakan teknik klasifikasi terbimbing (supervised classification). Teknik tersebut digunakan karena peneliti telah mengetahui kelas dari kriteria-kriteria untuk masing-masing variabel dalam penentuan lahan kritis hutan mangrove. Dalam klasifikasi penentuan variabel jenis penggunaan lahan dan kerapatan mangrove diatas tentunya membutuhkan keahlian seorang peneliti dalam observasi visual. Para peneliti membedakan menurut perbedaan antara karakteristik geometrik fitur permukaan jelas didasarkan pada pertumbuhan mangrove dan lingkungan sekitarnya. Itu penggabungan antara survei dan foto udara dengan bantuan penginderaan jauh dari warna citra, cahaya, fitur geometris, dan lokasi geografis. Kemudian melalui manusia-mesin interpretasi interaktif dan menetapkan berbagai fitur permukaan dan citra satelit sesuai dengan karakteristik yang relevan dari gambar digital menggunakan warna mata, penampilan dan penafsiran perbedaan. Hal ini sering digunakan dalam klasifikasi mangrove penginderaan jauh (Song Xue Fei et al, 2011).Proses pengklasifikasian citra dilakukan 2 kali karena menggunakan 2 data citra yaitu Citra Landsat 7 ETM+ Tahun 2009 dan Citra ALOS AVNIR-2 Tahun 2009.

Dalam penentuan variabel jenis penggunaan lahan, citra landsat dan ALOS menggunakan kombinasi band 321. Kombinasi band tersebut merupakan kombinasi paling umum dalam pengunaan citra karena menampilkan warna citra yang mendekati sebenarnya (true colour). Sedangkan dalam penentuan kerapatan tajuk, citra landsat mengunakan komposit antara band 3, 4 dan 5 (Murray et al, 2002), dan susunan kombinasi yang dirasa cocok dalam interpretasi habitat mangrove oleh peneliti adalah 453 . Kombinasi band tersebut merupakan kombinasi band yang umum dalam penggunaannya untuk penelitian vegetasi. Dalam kombinasi band tersebut vegetasi dapat dibedakan dengan warnanya yang jingga, dan habitat mangrove sendiri ditandai warna jingga yang lebih gelap. Untuk citra ALOS, kombinasi yang digunakan adalah 432. Kombinasi band tersebut digunakan bedasarkan percobaan beberapa kombinasi oleh peneliti, dan kombinasi tersebut yang dirasa cukup baik dalam interpretasi sebaran vegetasi khususnya mangrove dengan ditandai warna merah. Kemudian hasil dari pengklasifikasian tersebut digunakan sistem informasi geografis dalam proses overlay hasil dari masing-masing variable yang telah 
diketahui, dari hasil overlay tersebut diketahui peta tingkat kekritisan lahan hutan mangrove di Kecamatan Tugu, Kota Semarang.

\section{HASIL DAN PEMBAHASAN}

Jenis penggunaan lahan, variabel ini diperoleh dari hasil klasifikasi terbimbing melalui software ErMapper untuk setiap data citra yang digunakan yaitu Citra Landsat dan Citra ALOS dengan menggunakan komposisi band 321. Dari data citra tersebut jenis penggunaan lahan dapat dklasifikasikan menjadi 7 kelas atau region, diantaranya adalah hutan, tambak, perkebunan, pemukiman, industri, sawah, dan tanah kosong. Dari ketujuh kelas tersebut dapat diklasifikasikan lagi menjadi 3 kelas besar (Departemen Kehutanan, 2005), yaitu: 1) Hutan (kawasan hutan); 2) Tambak Tumpang Sari dan Perkebunan; 3) Areal Non-vegetasi Hutan (pemukiman, industri, tambak non-tumpangsari, sawah, dan tanah kosong).

Gambar 2. Klasifikasi penggunaan lahan dengan Landsat (analisis, 2014)

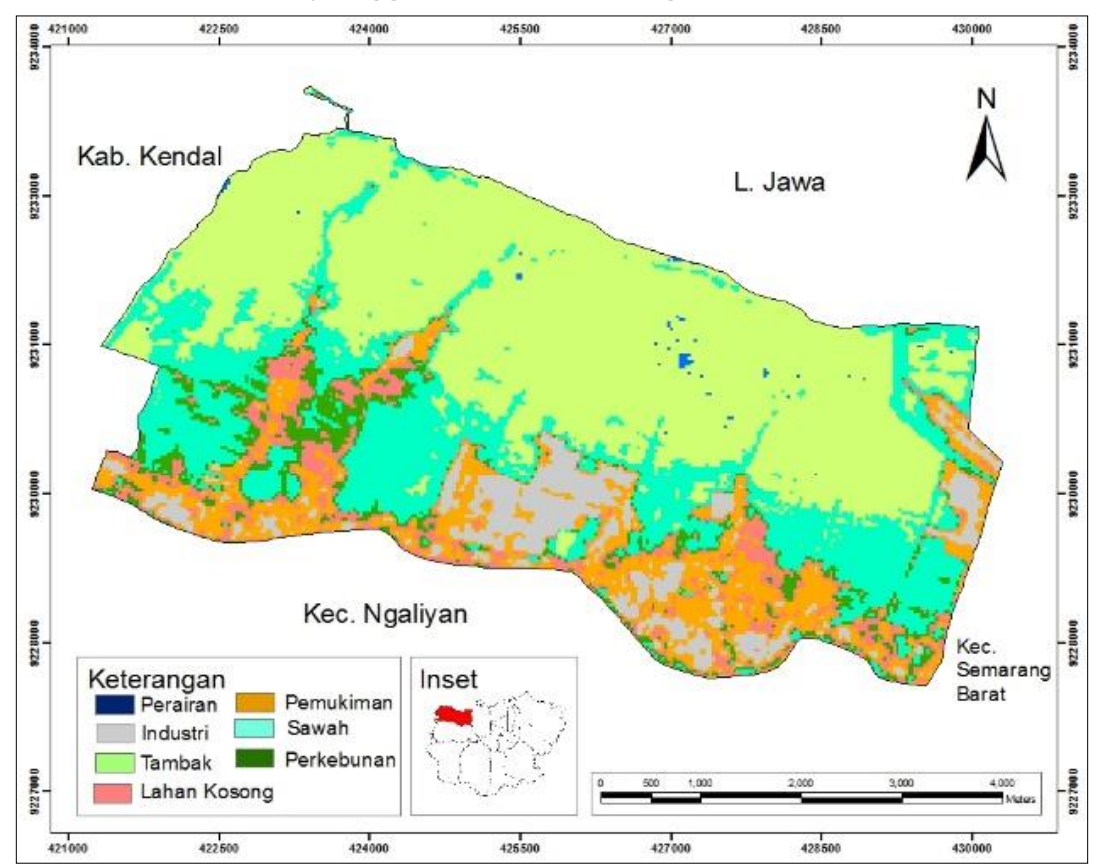

Gambar 3. Klasifikasi penggunaan lahan dengan ALOS (analisis, 2014)

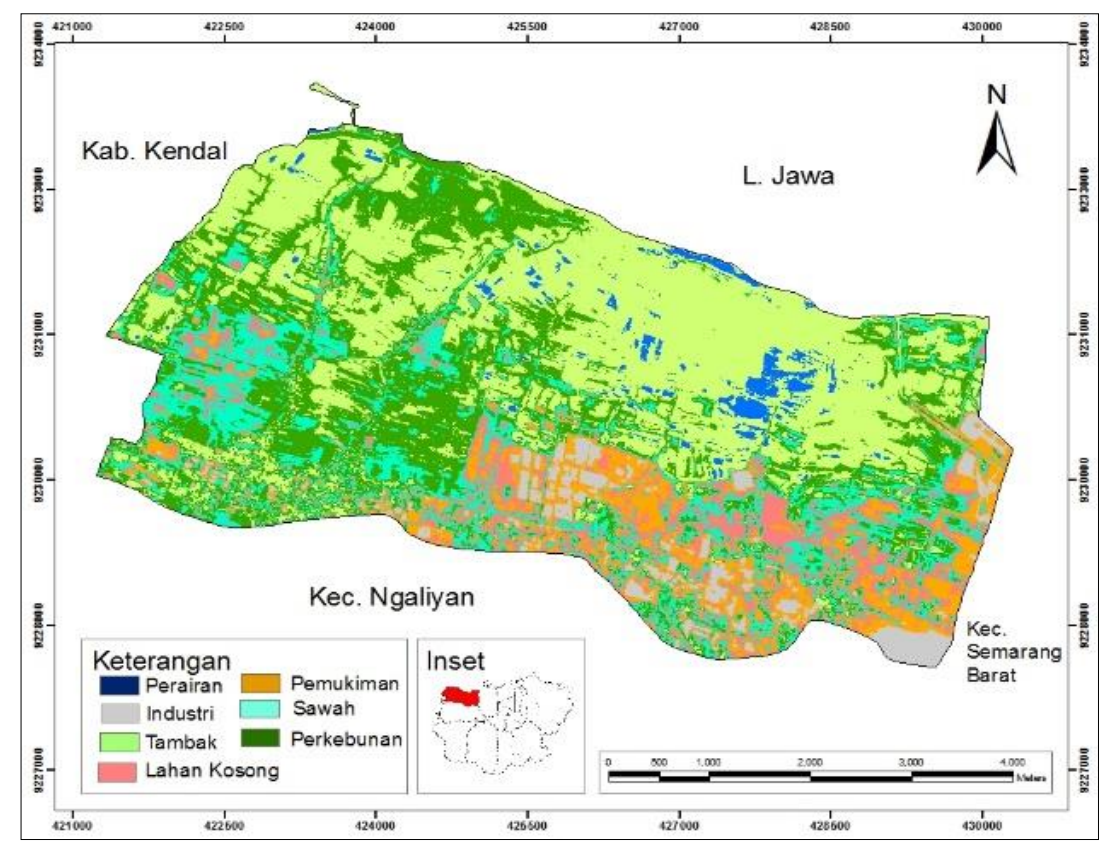


Kerapatan tajuk, diperlukan beberapa tahap analisis dalam penentuan variabel kerapatan tajuk ini dengan bantuan software ErMapper dan ArcGIS. Tahap pertama adalah pengklasifikasian secara terbimbingsebaran hutan mangrove di Kecamatan Tugu. Untuk klasifikasi sebaran hutan mangrove dengan menggunakan citra landsat, digunakan komposisi band 453, sedangkan Pada klasifikasi sebaran mangrove dengan menggunakan Citra ALOS, digunakan kombinasi band 432.

Gambar 4.Klasifikasi sebaran mangrove dengan Landsat (analisis, 2014)

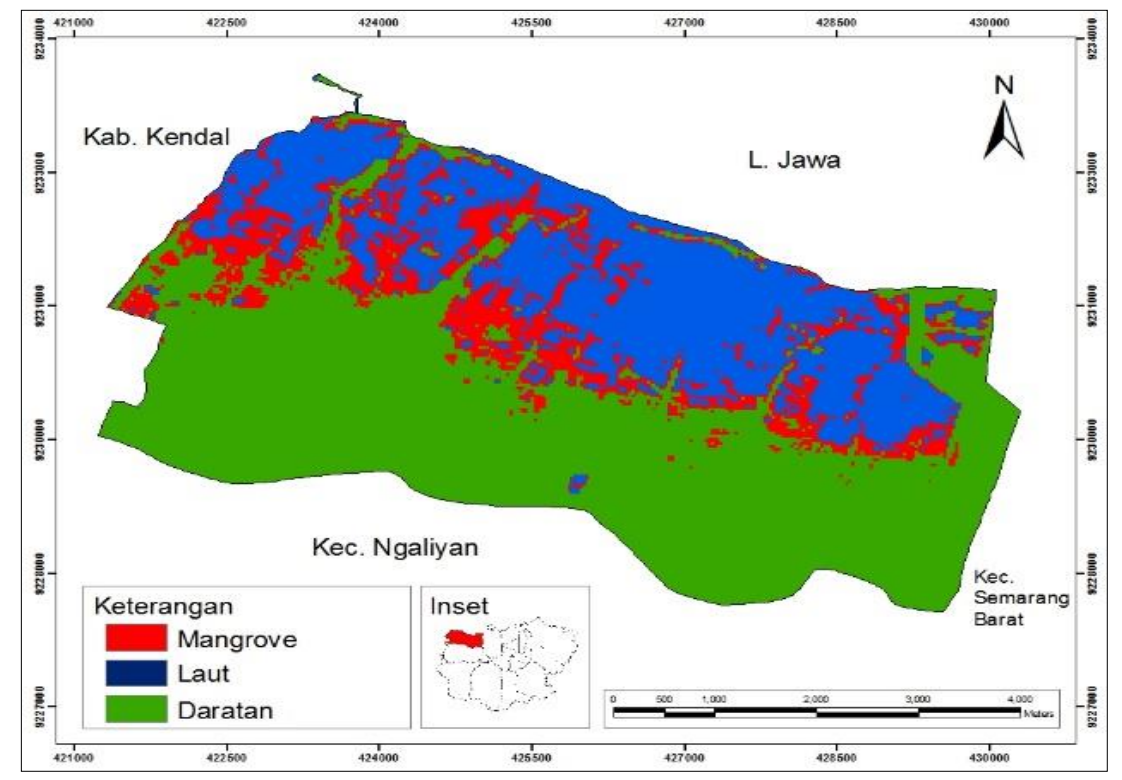

Gambar 5.Klasifikasi sebaran mangrove dengan ALOS (analisis, 2014)

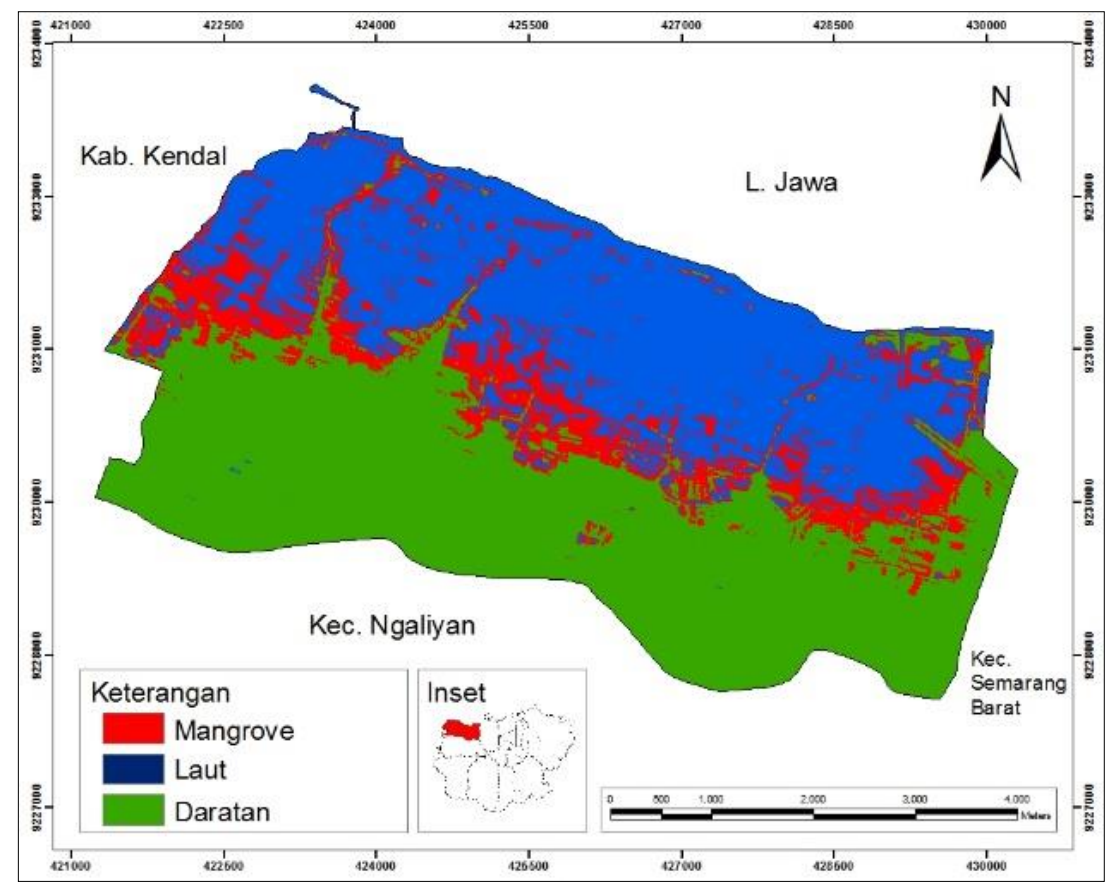

Tahap berikutnya adalah proses klasifikasi NDVI untuk mendapatkan klasifikasi kerapatan tajuk di Kecamatan Tugu. Hasil klasifikasi nilai NDVI dibagi menjadi 3 kelas (Dephut, 2005), yaitu: 1) Kerapatan tajuk lebat $(0,43 \leq \mathrm{NDVI} \leq 1,00) ; 2)$ Kerapatan tajuk sedang $(0,33 \leq \mathrm{NDVI} \leq 0,42)$; dan 3$)$ Kerapatan tajuk jarang ($1,00 \leq N D V I \leq 0,32$ ). 
Gambar 6. Klasifikasi NDVI Kecamatan Tugu dengan Landsat (analisis, 2014)

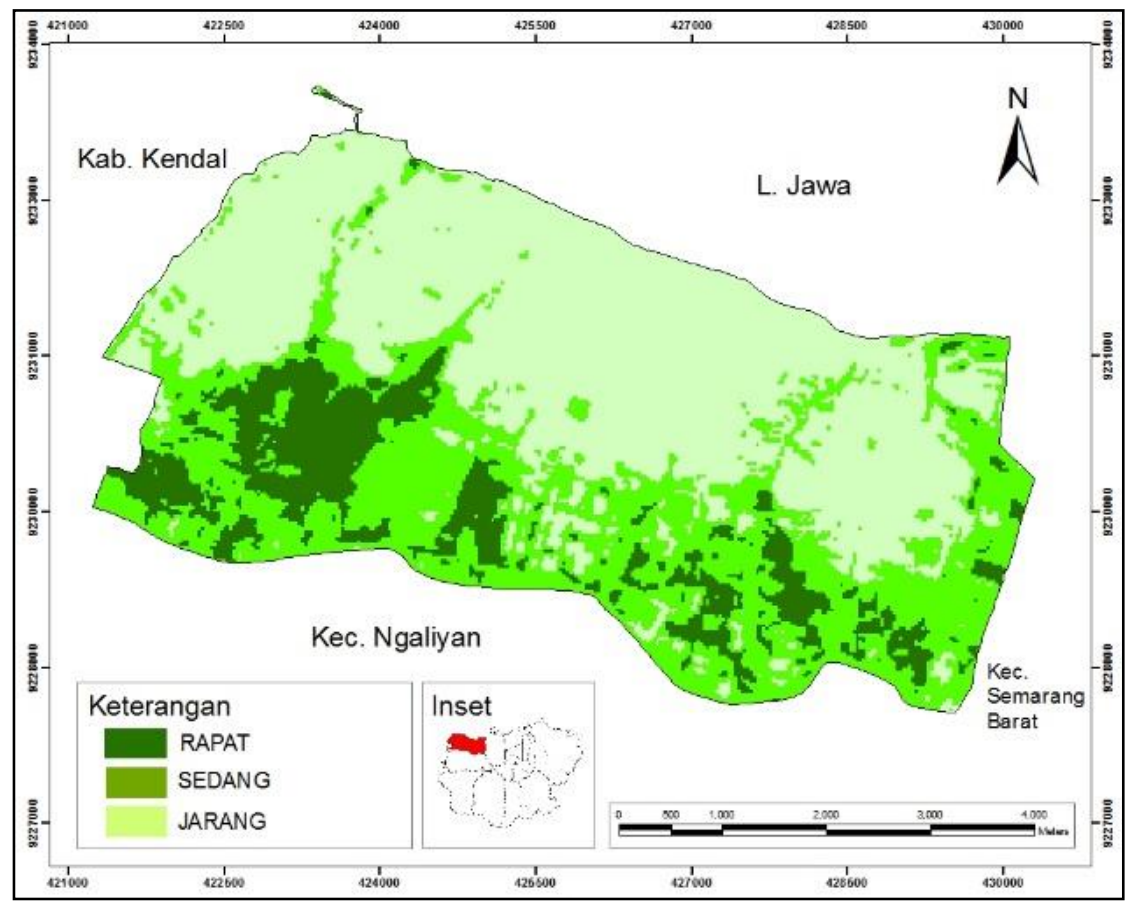

Gambar 7. Klasifikasi NDVI Kecamatan Tugu dengan ALOS (analisis, 2014)

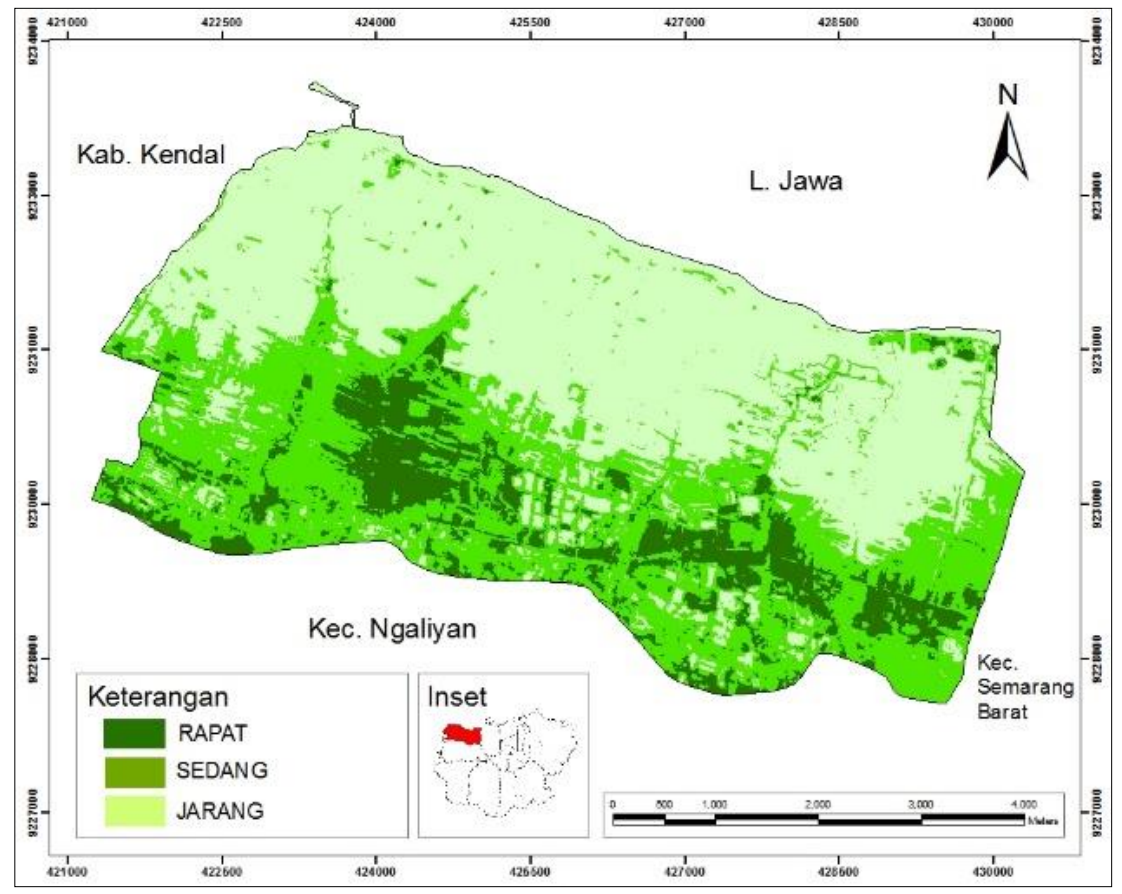

Dari hasil klasifikasi NDVI menjadi 3 kelas untuk masing-masing citra yang digunakan di atas, kemudian dilakukan penggabungan dengan Peta Klasifikasi Sebaran Mangrove di Kecamatan Tugu untuk masingmasing citra untuk memisahkan anata vegetasi mangrove dan vegetasi nonmangrove. Proses ini dilakukan pada program ArcGIS dengan perintah Clip, sehingga didapatkan kerapatan tajuk yang hanya terdiri dai vegetasi mangrove saja. 
Gambar 8. Analisis kerapatan tajuk mangrove dengan Landsat (analisis, 2014)

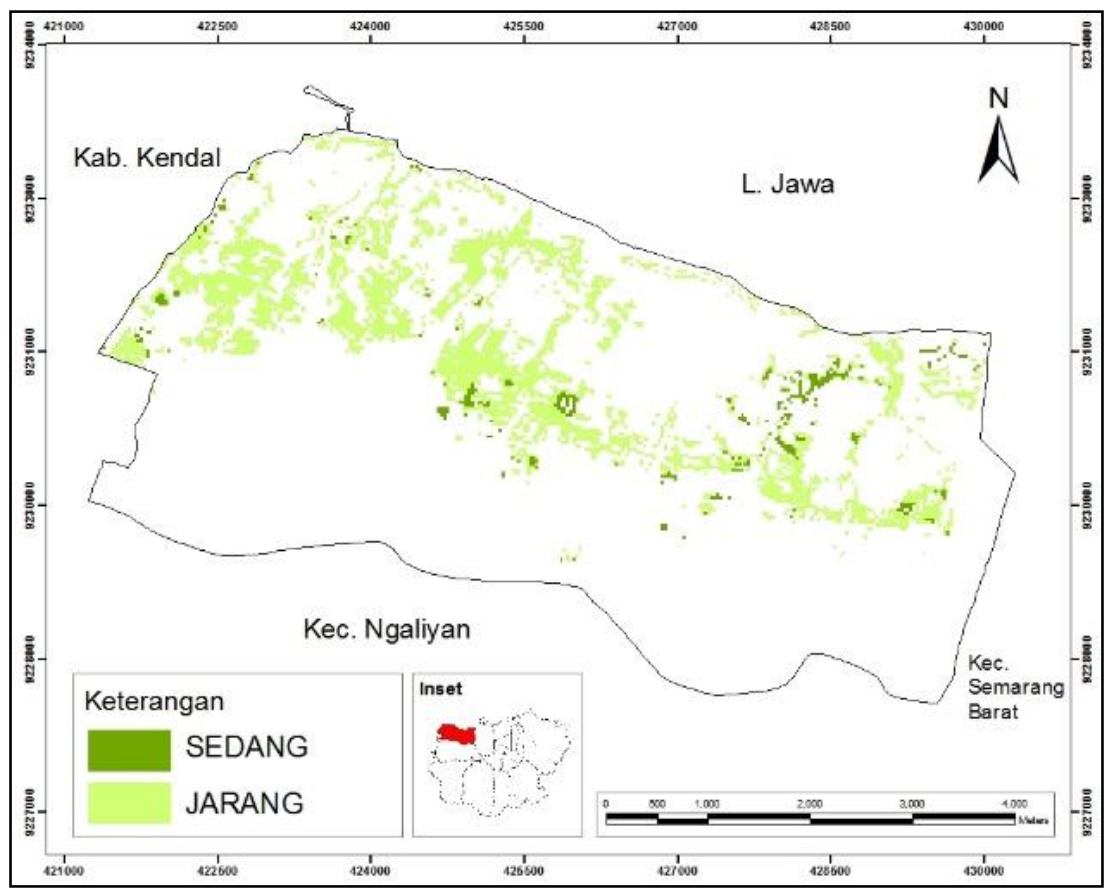

Gambar 9. Analisis kerapatan tajuk mangrove dengan ALOS (analisis, 2014)

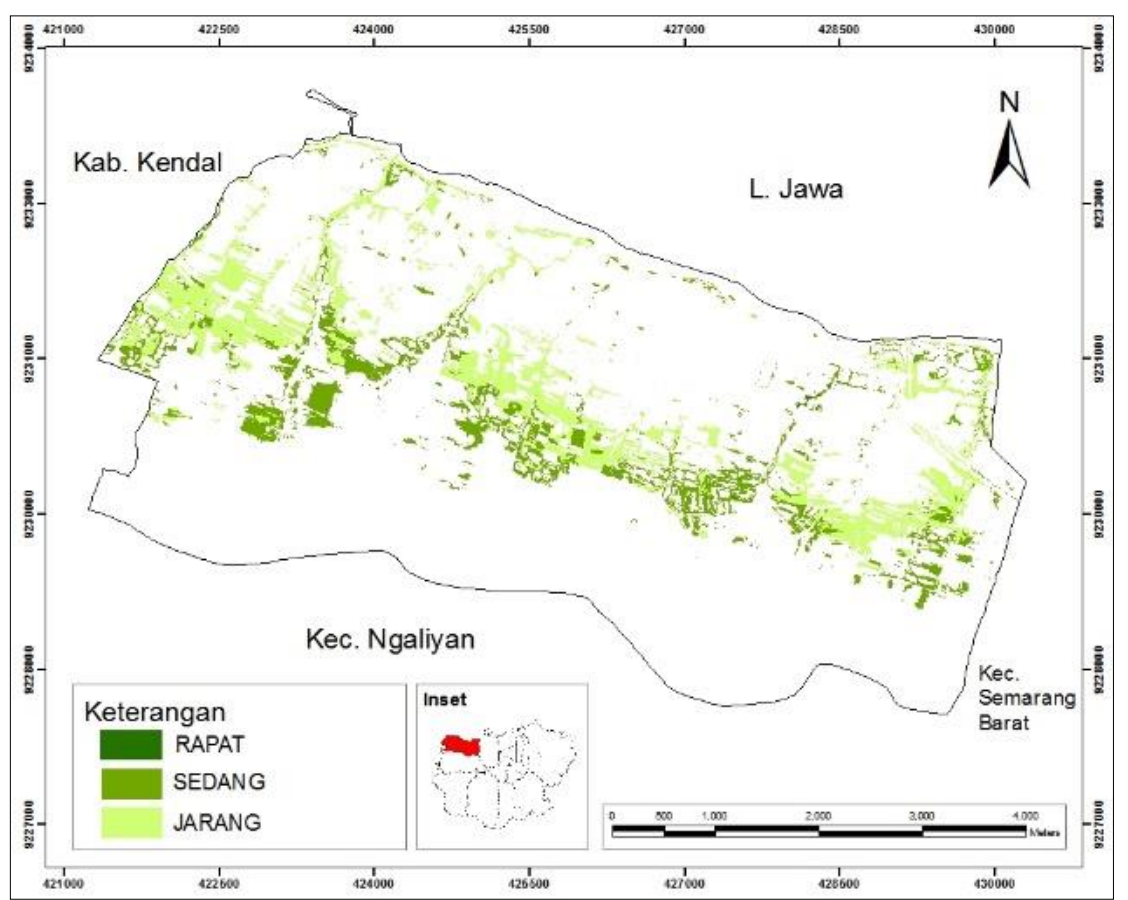

Ketahanan tanah terhadap abrasi, Untuk analisis ketahanan tanah terhadap abrasi di Kecamatan Tugu, diperlukan data berupa peta jenis tanah di Kecamatan Tugu. Data peta jenis tanah yang digunakan pada penelitian ini adalah data yang bersumber dari BAPPEDA tahun 2010. Dari Peta Jenis Tanah Kecamatan Tugu, kemudian diklasifikasikan menjadi 3 kelas (Dephut, 2005), yaitu: 1) Jenis tanah tidak peka erosi (tekstur lempung); 2) jenis tanah peka erosi (tekstur campuran); dan 3) jenis tanah sangat peka erosi (tekstur pasir). Jika ditelaah bedasarkan SK Menteri Pertanian (1980), jenis tanah alluvial dapat dikategorikan menjadi jenis tanah yang tidak peka erosi. Dari pernyataan tersebut maka dapat disimpulkan jenis tanah di seluruh wilayah Kecamatan Tugu dapat diklasifikasikan menjadi jenis tanah yang tidak peka erosi. 
Gambar 10. Jenis tanah di Kecamatan Tugu (Pemerintah Kota Semarang, 2014)

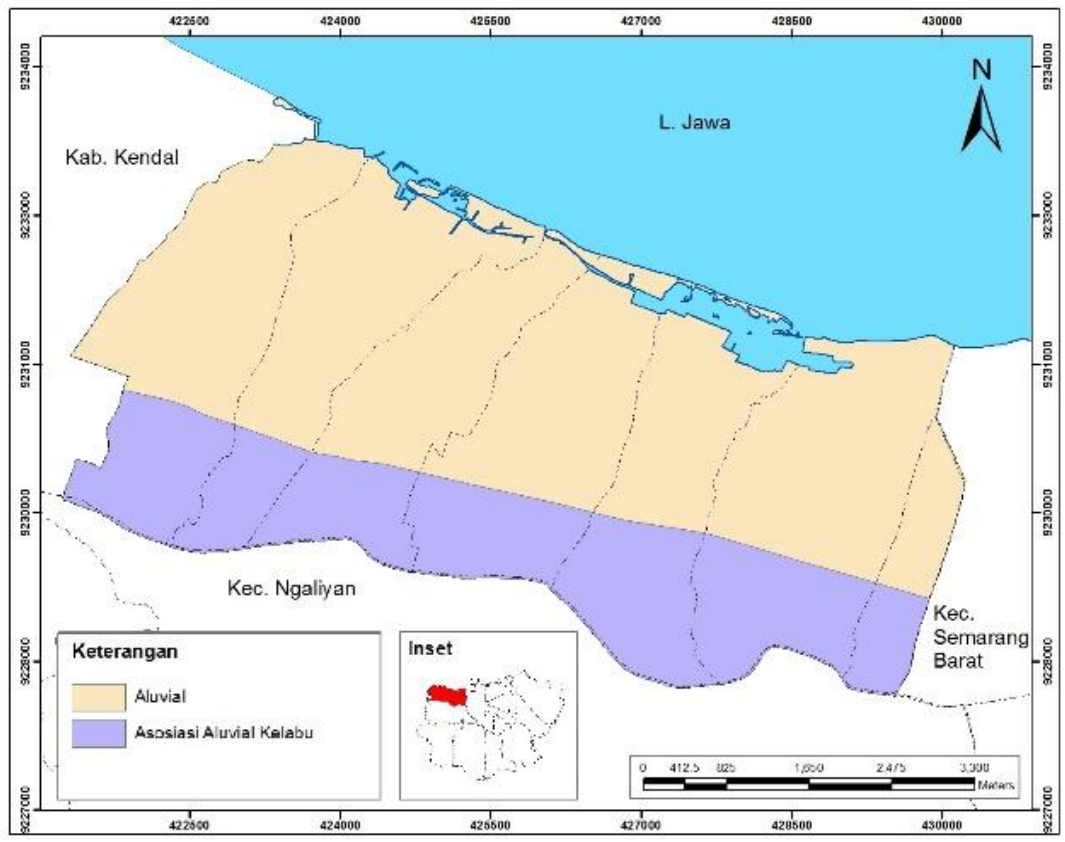

Gambar 11. Kepekaan tanah terhadap erosi di Kecamatan Tugu (analisis, 2014)

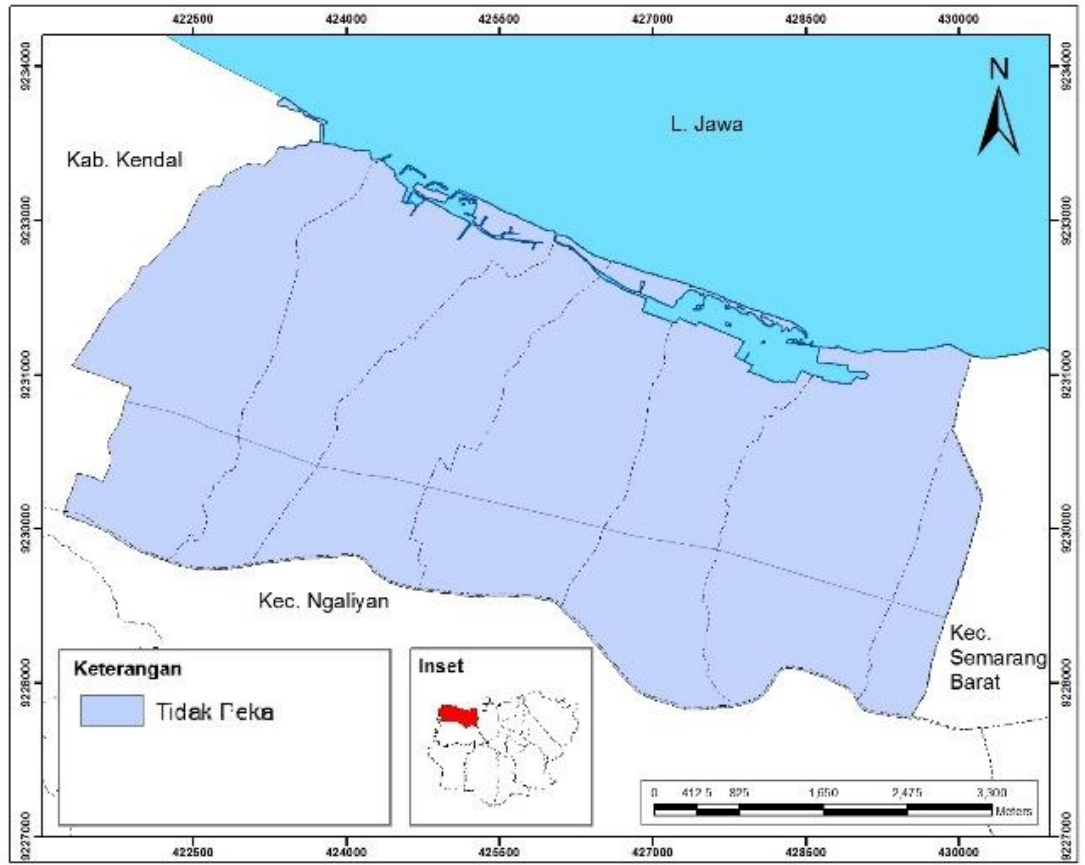

Lahan kritis mangrove, Setelah beberapa tahap dilakukan, langkah berikutnya adalah pembobotan atribut (skoring attribute) untuk menentukan lahan kritis mangrove di Kecamatan Tugu untuk masingmasing peta. Pembobotan ini dilakukan pada program ArcGIS dengan bantuan program Ms. Excell sebagai alat bantu untuk menuliskan rumus atau formula. Setelah dilakuan pembobotan untuk masing-masing peta, kemudian dilakukan penggabungan antara Peta Klasifikasi Jenis Penggunaan Lahan, Peta Kerapatan Tajuk Mangrove, dan Peta Kepekaan Tanah Terhadap Erosi. Penggabungan ketiga peta ini dilakukan dengan menu Intersect. 
Gambar 12. Lahan kritis mangrove berdasarkan Citra Landsat (analisis, 2014)

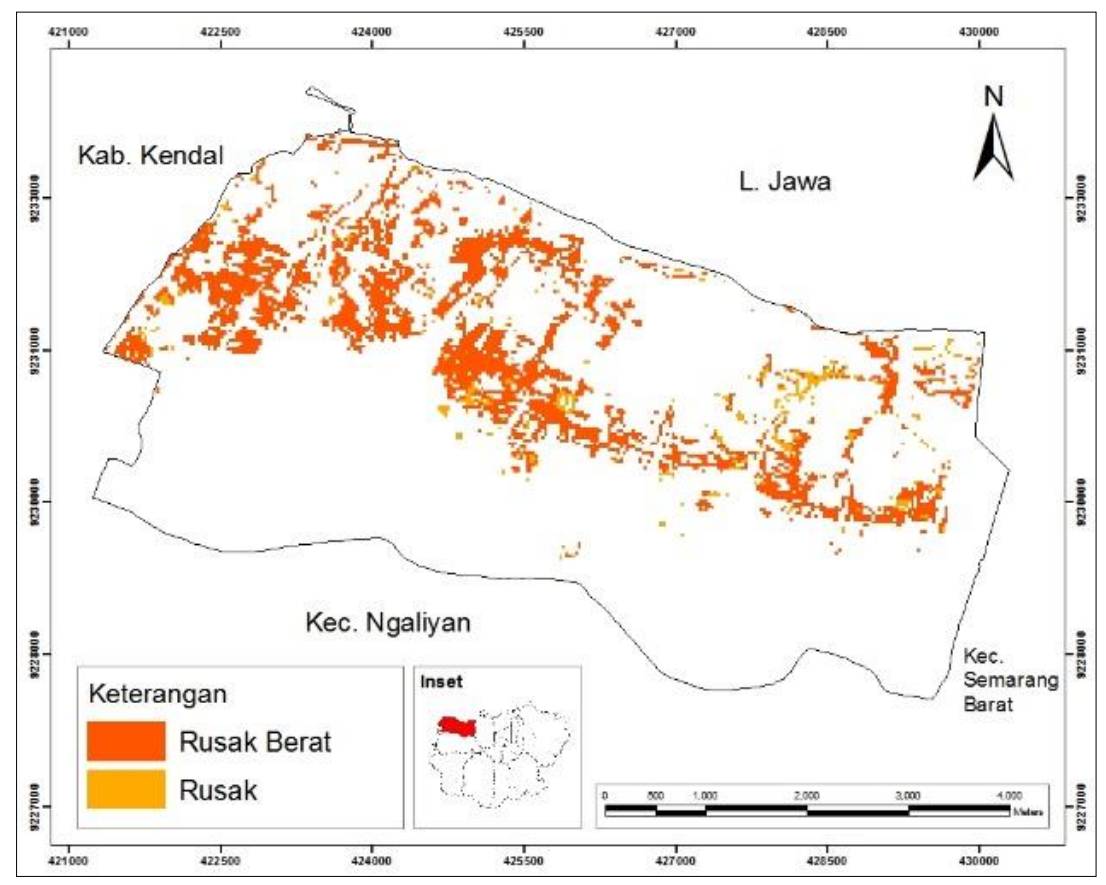

Gambar 13. Lahan kritis mangrove berdasarkan Citra ALOS (analisis, 2014)

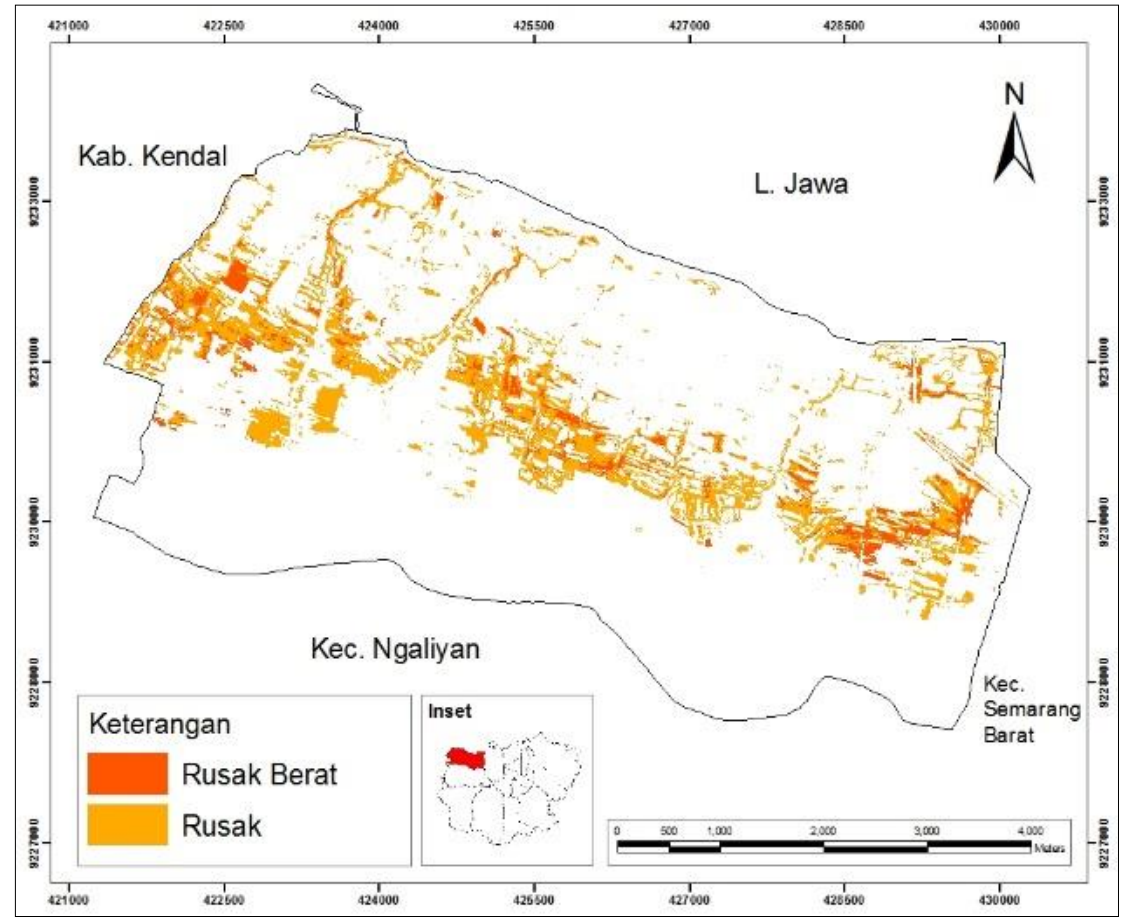

\section{KESIMPULAN}

Dari penelitian yang telah dilakukan, dapat disimpulkan bahwa kondisi mangrove di Kecamatan Tugu sangat memprihatinkan. Jika dilihat dari hasil klasifikasi lahan kritis bedasarkan Citra Landsat lebih dari sekitar 92,22\% kawasan hutan mangrove termasuk dalam kondisi rusak berat dan sisanya sekitar 7,78\% termasuk dalam kategori rusak, sedangkan bedasarkan hasil dari Citra ALOS sebanyak 77,73\% kawasan mangrove di Kecamatan Tugu termasuk dalam kondisi rusak berat dan sisanya sebesar 22,27\% termasuk dalam kategori rusak berat. Tidak ada satu lokasi pun di Kecamatan Tugu yang memiliki klasifikasi hutan mangrove yang tergolong dalam kategori tidak rusak. Terdapat perbedaan perbandingan antara kondisi lahan kritis dengan kategori rusak dan rusak berat untuk Citra ALOS dan Citra Landsat. Pada Citra ALOS 
perbandingan keduanya hanya sekitar 3:7, akan tetapi untuk Citra Landsat perbandingannya mencapai 1:9. Citra Landsat lebih banyak mengklasifikasikan lahan kritis menjadi kategori rusak, hal tersebut mengindikasikan bahwa Citra Landsat kurang dapat mengklasifikasikan kerapatan tajuk dengan baik. Hal ini dapat disebabkan oleh berbagai faktor. Salah satunya adalah resolusi spasial yang lebih rendah, sehingga kurang dapat menangkap nilai spektral yang sebenarnya dari klasifikasi NDVI, kemudian diklasifikasikan menjadi kerapatan tajuk yang rendah.

Jika ditelaah bedasarkan validasi di lapangan, peta lahan kritis mangrove yang dihasilkan oleh Citra Landsat memiliki nilai validitas sebesar $37,5 \%$ dari total titik sampel yang diambil, sedangkan peta lahan kritis mangrove yang dihasilkan bedasarkan Citra ALOS memiliki nilai validitas sebesar 62,5\%. Maka dapat disimpulkan pula bahwa Citra Landsat kurang dapat mempresentasikan kondisi lapangan dengan baik karena hanya memiliki nilai validitas sebesar $37,5 \%$ dari titik sampel yang divalidasi. Akan tetapi jika dilihat dari luasan dan sebaran mangrove, kedua citra yang digunakan sudah dapat mempresentasikan kondisi di lapangan dengan baik.

Dari beberapa hal yang telah dijabarkan diatas, dapat disimpulkan kembali bahwa kedua citra yang digunakan dalam penelitian ini yaitu Citra ALOS dan Citra Landsat sebenarnya sudah baik dalam penggunaannya untuk penentuan lahan kritis mangrove dalam hal luasan dan sebaran hutan mangrove di suatu kawasan. Akan tetapi peta lahan kritis mangrove yang dihasilkan oleh Citra Landsat kurang dapat mempresentasikan secara baik untuk detail pengklasifikasian kondisi lahan kritis mangrove di Kecamatan Tugu.

Dalam pemilihan atau penggunaan data citra dalam penelitian bedasarkan penginderaan jauh dan atau sistem informasi geografis khususnya dengan subjek penelitian mangrove. Citra yang memiliki resolusi spasial lebih besar merupakan data citra yang lebih baik dalam pengklasifikasian kategori lahan kritis mangrove dibandingkan citra yang memiliki resolusi spasial lebih kecil. Hal tersebut didasarkan oleh hasil penelitian diatas yang menyatakan bahwa Citra ALOS lebih dapat mengklasifikasikan kerapatan tajuk dengan baik secara detail klasifikasi lahan kritis mangrove dibandingkan dengan Citra Landsat. Pemilihan data citra dengan resolusi spasial yang lebih baik tentunya menjadi prioritas dalam penelitian lahan kritis mangrove baik untuk kalangan pemerintahan maupun akademisi. Penggunaan Citra Landsat yang telah menjadi standar dalam Pedoman Inventarisasi Dan Identifikasi Lahan Kritis Mangrove yang dikeluarkan oleh Departemen Kehutanan harus ditinjau ulang. Karena semakin besar resolusi spasial dari data citra yang dipakai untuk penelitian, maka semakin baik dan semakin valid pula hasil yang diperoleh dari penelitian tersebut.

Jika dilihat dari hasil klasifikasi lahan kritis mangrove di Kecamatan Tugu dibandingkan dengan rencana tata ruang yang ada, rekomendasi yang dapat diberikan adalah pembangunan tanggul pantai untuk penanggulangan bencana rob dan banjir di Kota Semarang hanya pada lokasi lahan kritis dengan kondisi rusak berat saja. Mengingat pembangunan pantai membutuhkan biaya yang tidak sedikit. Sedangkan lokasi lahan kritis dengan kondisi rusak, dilakukan reboisasi atau rehabilitasi hutan mangrove mengingat tumbuhan mangrove membutuhkan waktu untuk tumbuh sehingga dapat menghalau gelombang laut dengan kuat. Selain itu, perlu juga adanya penegakan hukum yang tegas untuk berbagai jenis pelanggaran yang dapat menyebabkan kerusakan habitat mangrove di Kecamatan Tugu pada khususnya dan pesisir pantai Kota Semarang pada umumnya, baik dalam gangguan fisik, kimia maupun biologis. Karena tidak akan berarti perencanaan yang menyangkut tentang mangrove dibuat, akan tetapi dalam implementasi di lapangan masih tidak ada ketegasan.

\section{DAFTAR PUSTAKA}

Arief, A. 2003. Hutan Mangrove Fungsi dan Manfaatnya. Yogyakarta: Kanisius.

BAPPEDA Kota Semarang. 2012. Lokakarya Nasional - Integrasi Adaptasi Perubahan Iklim Dan Pengurangan Resiko Bencana Dalam Kebijakan, Pembangunan Dan Penganggaran Keuangan Daerah. Badan Perencanaan Pembangunan Daerah Kota Semarang.

Bengen, Dietriech G. 2000. Sinopsis Ekosistem dan Sumberdaya Alam Pesisir. Bogor: Pusat Kajian Sumberdaya Pesisir dan Lautan-IPB.

Departemen Kehutanan. 2005. Pedoman Inventarisasi Dan Identifikasi Lahan Kritis Mangrove. Direktorat Jenderal Rehabilitasi Lahan Dan Perhutanan Sosial. 
Landgrebe, D.A. 2003. Signal Theory Methods In Multispectral Remote Sensing. New Jersey: John Willey \& Sons Inc.

Murray, M.R et al. 2003. "The mangroves of Belize. Part 1: distribution, composition and classification". Elsevier Science B.V. Forest Ecology and Management Vol. 174: 265-279.

Peraturan Daerah Kota Semarang Nomor 7 Tahun 2010. Tentang Penataan Ruang Terbuka Hijau (RTH).

Purwadhi dan Sri Hadiyanti. 2001. Interpretasi Citra Digital. Jakarta: Grasindo.

RTRWP Kota Semarang. 2009. Rencana Tata Ruang Pesisir Kota Semarang 2009. Dinas Kelautan dan Perikanan Kota Semarang

Song Xue Fei et al. 2011. "Remote Sensing of Mangrove Wetlands Identification". Elsevier Ltd. Procedia Environmental Sciences Vol. 10: 2287 - 2293.

SK Dirjen Kehutanan. 1978. Surat Keputusan Direktorat Jenderal Kehutanan No.60/Kpts/DJ/1978. Direktorat Jenderal Kehutanan.

SK Menteri Pertanian. 1980. Surat Keputusan Menteri Pertanian No. 837/Kpts/Um/11/1980. Kementrian Pertanian.

Susetiono. 2005. Krustasea dan Molluska Mangrove Delta Mahakam. Jakarta: Pusat Penelitian Oseanografi. Lembaga Ilmu Pengetahuan Indonesia. 